\title{
Role of Public Sector Bank in Financial Inclusion of Low or Middle Income Group in Chennai
}

\author{
Keerthika. R, Anli Suresh
}

\begin{abstract}
The role of public sector bank, in raising the economic equality on low income or middle income group, the term financial inclusion emphasis on redistribution of income within the same household, the deprive section of society avail the benefit with some standard provided by the government and how the approach have been taken by public sector bank to distribute the same and their behavioral ethics trail over the schemes. The study focused the dominant properties which fabricate imperative on financial inclusion among various categories of customers in public sector banks and also investigated the recognition of public in stand point of financial assistance and financial features offered by public sector bank through correlation statistical analysis with the sample of 200 with Chennai arena..
\end{abstract}

Keywords : government, financial inclusion, low or middle income group, public sector bank, schemes.

\section{INTRODUCTION}

$\mathrm{F}_{\text {inancial inclusion has been major term coined for the }}$ purpose of equal discrete in development which remains unequal due to various reason and behavioral ethics of citizen. India is a country covered with major part of low income or middle income group which has been detached and separated with association to development and its benefits to the limited zone of economy. The term financial inclusion is crucial for attaining comprehensive development within the focused zone. It will regularize or help in decreasing the extension of unauthorized source of credit funds (such as pawn brokers or any unauthorized lenders), that are typically narrowed to be exploitive.Commercial banks do play a vital role when it comes to the implementation part of financial inclusion. The financial system is said to be key pillars of the country. Besides opening of accounts, Green channel counter, Kissan credit card, micro insurance, bank is also doing other activities for accelerating the growth of financial inclusion. Banks also bridges the gap between the society and the financial sector Besides this, they introduce financial services exclusively for people below or on the poverty line, providing improved services to rural clients more than urban surroundings who have better knowledge of same by introducing innovative technological assistance, providing funding to financial

Revised Manuscript Received on December 05, 2019.

* Correspondence Author

Keerthika.R*, Research Scholar, University of Madras, Chennai, India. Email: keerthikaravikumar7@gmail.com

Dr. Anli Suresh, Assistant Professor, Department of Commerce, Madras Christian College, Chennai, India. Email: anli.sgain@gmail.com

institutions for the better adaptation in all financial product involved with transaction and cost benefit features, transparency of service over funds and other benefits which results in empowerment of farmers.

\section{LITERATURE REVIEW}

According to Ramesh Iyer 14 Jan 2019 in his article published on the topictitled"financial inclusion in India is soaring. Here's what must happen next" which was taken part in meeting held by world economic forum(WEF) discussion on financial inclusion which will actively play the base of economic strategy and include the younger generation and class which is below poverty line to schedule in proper channel tuning up over the massive economic reconstruction.

According toCharan Singh and GopalNaik (2017) in their paper published on IAM research paper Bangalore on the topic titled "Financial Inclusion in India: A Case Study of Gubbi", financial inclusion plays key role in the country for economic stability and due to the lack of technological skills and illiteracy to the acquatency services analysis leads bank over the failure of certain models

SethySusanta Kumar (2016) in his research study has stated about value Inclusion Index to live the expanded of financial inclusion across economic zone. Each view the features like access to savings of fund, insurance of risk, banking risk and demand aspect extended over the field of banking penetration, availability of banking system and services which used as main criteria of development of index. It had been discovered that India is categorized with fluctuation of high and low money demand on inclusion over provide aspect. It had been suggested that government of india should take over more policy steps to boost provide aspect view of monetary inclusion.

According to M.P.Desai (2016)in his research published on topic "Present Scenario of Financial Inclusion In India" talks about development of banking sectors with advancement and technological improvement include the deprived section of society to gain some standing and focuses of the need and possibility of affordable over services helps them to ascertain the services with more confident.

Bharati D.B (2016) the author observed the situation and stated that allowing access to financing idea may lead to divide of authorization of the unprotected groups that contains a set of problems and drawbacks that must be addressed by them on their own.

Published By:

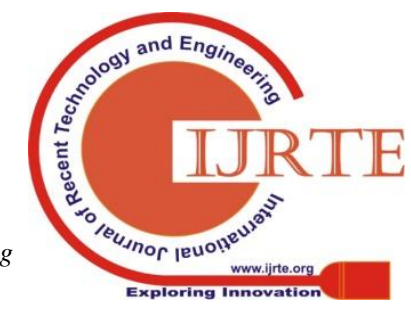


From the available demand, the reasons found with the study for monetary exclusion are low financial gain, financial condition and illiteracy and lack of awareness.

\section{RESEARCH GAP}

While this study makes a contribution to our understanding over the public sector bank in the economic services to the low income and middle income group, since the vast subject is narrowed down to the population which is yet to be brought under cover and requirement essential to identify the most influencing means of communication in disseminating the financial knowledge, due to the limited time constrain the study is minimized to the particular geographical location.

\section{RESEARCH OBJECTIVE}

The study mainly focused on the active participation taken by the public sector bank to reach the economy in to stabilized factor of equality in growth with the side government in arena of financial inclusion, the country with majority of population falls under middle income or low income below poverty line, and their behavioral pattern towards the economic services opted.

\section{OBJECTIVES OF THE STUDY}

- To study analyzed the dominant properties which fabricate imperative on financial inclusion among various categories of customers in public sector banks.

- The study focused on analyzing the recognition of public in stand point of financial assistance and financial features offered by public sector bank.

\section{RESEARCH METHODOLOGY}

Table 1: Research Methods Endorsed In This Study

\begin{tabular}{|c|c|}
\hline $\begin{array}{l}\text { Research } \\
\text { carried }\end{array}$ & $\begin{array}{l}\text { Descriptive, qualitative, investigative and } \\
\text { expressive research design }\end{array}$ \\
\hline $\begin{array}{l}\text { Sampling Technique } \\
\text { used }\end{array}$ & Convenience sampling method \\
\hline Sampling Unit of study & $\begin{array}{l}\text { Public sector banks, government schemes, and } \\
\text { bank services }\end{array}$ \\
\hline $\begin{array}{l}\text { Sample Size of the } \\
\text { study }\end{array}$ & 200 \\
\hline Research Instrument & $\begin{array}{l}\text { Structured questionnaire on printed format with } \\
\text { scored using a five-point Likert scale }\end{array}$ \\
\hline $\begin{array}{l}\text { Data } \\
\text { method }\end{array}$ & $\begin{array}{l}\text { Made Physical visit to the respondent's } \\
\text { organization and interviews }\end{array}$ \\
\hline Statistical Techniques & Explanatory statistics, factor analysis techniques \\
\hline
\end{tabular}
$10 \%$ belongs to other categories. sector banks

\begin{tabular}{|c|c|c|}
\hline \multicolumn{3}{|c|}{ Gender } \\
\hline Particular & Frequency & Percent \\
\hline Male respondent & 59 & 28.7 \\
\hline Female respondent & 141 & 70.5 \\
\hline Total respondent & 200 & 100.0 \\
\hline \multicolumn{3}{|c|}{ Age } \\
\hline Particular & Frequency & Percent \\
\hline $18-25$ & 80 & 40.0 \\
\hline $26-35$ & 61 & 30.5 \\
\hline $36-45$ & 21 & 10.5 \\
\hline $46-54$ & 19 & 9.5 \\
\hline above 55 & 19 & 9.5 \\
\hline Total & 200 & 100 \\
\hline \multicolumn{3}{|c|}{ Qualification } \\
\hline Particular & Frequency & Percent \\
\hline Higher secondary & 16 & 8.0 \\
\hline Graduation & 91 & 45.5 \\
\hline Post- graduation & 73 & 36.5 \\
\hline Others & 20 & 10.0 \\
\hline Total & 200 & 100.0 \\
\hline
\end{tabular}

Interpretation: The total respondents of 200 on which $51.7 \%$ denoted male and $48.3 \%$ are female samples, the age factors of respondents $40 \%$ belong to age group under $18-25$, while $30.5 \%$ are under age group of 26-35 while $10.5 \%$ falls over age factor 36-45 and age 46-54 falls $9.5 \%$ of sample remaining groups under people who are above 55 years. The qualification of respondents is classified higher secondary $8.0 \%, 45.5 \%$ are graduates, $36.5 \%$ are post graduates and

Components which influence the low or middle income group to take part in financial inclusion through public

Table: 3 KMO and Bartlett's Test

\begin{tabular}{|c|c|c|}
\hline \multirow{3}{*}{ Kaiser-Meyer-Olkin Measure of Sampling Adequacy. } & .782 \\
\cline { 2 - 3 } Bartlett's Test of Sphericity & Approx. Chi-Square & 257.797 \\
\cline { 2 - 3 } & Df & 45 \\
\cline { 2 - 3 } & Sig. & .000 \\
\hline
\end{tabular}

Interpretation: The study has been conducted with Kaiser-Meyer-Olkin(KMO) and Bartlett's Test, the sample adequacy has been measured with result of $78 \%$ accuracy. 
Table 4: The total variances explain the factor elements towards delightful components which influence low or middle income group to take part in financial inclusion through public sector banks

\begin{tabular}{|c|c|c|c|}
\hline \\
\hline & \multicolumn{3}{|c|}{ Components } \\
\hline & 1 & 2 & 3 \\
\hline GOVERNMENT INITIATIVES & \multirow[b]{2}{*}{.747} & & \\
\hline PradhanMantri Jan DhanYojana & & & \\
\hline Self- help groups & .721 & & \\
\hline $\begin{array}{l}\text { To avail Government beneficial } \\
\text { schemes }\end{array}$ & .607 & & \\
\hline FINANCIAL ASSISTANCE & & \multirow[b]{2}{*}{.728} & \\
\hline Gold loan & & & \\
\hline Low interest loan from government & & .707 & \\
\hline Personal loan & & .503 & \\
\hline $\begin{array}{l}\text { Get EMI for home aids/ vehicles/ } \\
\text { electronics }\end{array}$ & & .677 & \\
\hline FUTURE RELIANCE & & & \multirow[b]{2}{*}{.804} \\
\hline Employee provident fund & & & \\
\hline Savings & & & .674 \\
\hline
\end{tabular}

Source: Primary Data Analysis

Interpretation: The mentioned table above has explains the percentage of variance explained in each derived factor elements towards delightful components which influence low or middle income group to take part in financial inclusion through public sector banks to influence people in low income or middle income group to leaver towards financial inclusion, the components were divided in to three major category, government active participation on which PradhanMantri Jan DhanYojana has been most favored factor of $74.7 \%$ followed by Self- help groups has more grip in rural as well as some part of urban sectors and some customer avail for schemes provided by the government. The second category was Financial assistance where availability of features like gold loan $72.8 \%$, low interest loan, easy monthly installment benefits along which personal loan also plays major role, that low income or middle income group volunteer themselves in for case of future reliance avail Employee provident fund $80 \%$ inducement in participating themselves in financial inclusion following foot step savings considered as active reason.

\section{Correlation Study}

H1- There is no noted difference within qualification and awareness of loans availability by the customers of public sector bank.

H2- There is no noted difference with factor of qualification and recognition of internet and mobile banking by the customers.

H3- There is no noted difference with awareness of life insurance policy by the customers and qualification factor.

H4- There is no noted difference between qualification and awareness of credit and debit cards by the customers.

H5- There is no noted difference between qualification and understanding knowledge of financial products offered by the bank to clients.

A

Table - 5: Correlation

\begin{tabular}{|c|c|c|c|c|c|c|c|}
\hline & & Qualification & Loans & $\begin{array}{l}\text { Internet } \\
\text { Banking }\end{array}$ & $\begin{array}{c}\text { Mobile } \\
\text { Banking } \\
\end{array}$ & $\begin{array}{c}\text { Credit/Debit } \\
\text { Card }\end{array}$ & $\begin{array}{c}\text { Financial } \\
\text { Product }\end{array}$ \\
\hline \multirow{3}{*}{ Qualification } & Correlation & 1 & $.198 * *$ & .094 & .089 & $.181 *$ & -.085 \\
\hline & Sig.(2-tailed) & & .005 & .184 & .212 & .010 & .230 \\
\hline & $\mathrm{N}$ & 200 & 200 & 200 & 200 & 200 & 200 \\
\hline \multirow{3}{*}{ Services loans } & Correlation & $.198 * *$ & 1 & $.535 * *$ & $.459 * *$ & $.228 * *$ & -.073 \\
\hline & Sig. (2-tailed) & .005 & & .000 & .000 & .001 & .301 \\
\hline & $\mathrm{N}$ & 200 & 200 & 200 & 200 & 200 & 200 \\
\hline \multirow{3}{*}{$\begin{array}{c}\text { Internet /mobile } \\
\text { banking }\end{array}$} & Correlation & .094 & $.535 * *$ & 1 & $.543 * *$ & $.271 * *$ & -.124 \\
\hline & Sig. (2-tailed) & .184 & .000 & & .000 & .000 & .081 \\
\hline & $\mathrm{N}$ & 200 & 200 & 200 & 200 & 200 & 200 \\
\hline \multirow{3}{*}{ Life insurance policy } & Correlation & $.385 * *$ & 1 & .093 & .068 & -.005 & \\
\hline & Sig. (2-tailed) & .000 & & .189 & .340 & .949 & \\
\hline & $\mathrm{N}$ & 200 & 200 & 200 & 200 & 200 & \\
\hline \multirow{3}{*}{ Credit/debit card } & Correlation & $.181 *$ & $.228 * *$ & $.271 * *$ & $.328 * *$ & 1 & -.080 \\
\hline & Sig. (2-tailed) & .010 & .001 & .000 & .000 & & .259 \\
\hline & $\mathrm{N}$ & 200 & 200 & 200 & 200 & 200 & 200 \\
\hline \multirow{3}{*}{$\begin{array}{l}\text { Financial product and } \\
\text { other services }\end{array}$} & Correlation & -.085 & -.073 & -.124 & -.104 & -.080 & 1 \\
\hline & Sig. (2-tailed) & .230 & .301 & .081 & .144 & .259 & \\
\hline & $\mathrm{N}$ & 200 & 200 & 200 & 200 & 200 & 200 \\
\hline \multicolumn{8}{|c|}{ **. $\mathrm{r}$ is significant at the level of 0.01 which is 2 -tailed. } \\
\hline \multicolumn{8}{|c|}{ *. $\mathrm{r}$ is significant at the level of 0.05 which is 2 -tailed } \\
\hline
\end{tabular}

Source: Primary Data Analysis 


\section{Interpretation:}

H1- There is no noted difference within qualification and awareness of loans availability by the customers of public sector bank.

The correlation table shows that the $r$ of correlation value for the relationship between qualification and awareness of loans is 0.198 . This states that there is a moderate positive relationship between these variables in financial literacy process. Thus the null hypothesis H1- There is no noted difference within qualification and awareness of loans availability by the customers of public sector bank is rejected. H2- There is no noted difference with factor of qualification and recognition of internet and mobile banking by the customers

The correlation table shows that the $r$ of correlation value for the relationship between qualification and recognition of internet banking is 0.535 . This indicates that there is a weakness in the positivity of relationship between these variables in financial literacy process. Thus the null hypothesis is rejected.

H3- There is no noted difference with awareness of life insurance policy by the customers and qualification factor.

The correlation table shows that the $r$ of correlation value for the relationship between qualification and awareness of life insurance policy is 0.212 . This indicates that there is a moderate level in positivity of relationship between these variables in financial literacy process. Thus the null hypothesis is rejected.

H4- There is no noted difference between qualification and awareness of credit and debit cards by the customers

The correlation table shows that the $r$ of correlation value for the relationship between qualification and awareness of credit and debit card is 0.228 . This indicates that there is a moderately level positive exist in relationship between these variables in financial literacy process. Thus the null hypothesis is rejected.

H5- There is no noted difference between qualification and understanding knowledge of financial products offered by the bank to clients.

The correlation table shows that the $r$ of correlation value for the relationship between qualification and financial products is -.073. This indicates that there is a negative relationship exists between these two variables in financial literacy process. Thus the null hypothesis is accepted.

\section{FINDINGS}

The study have been analyzed the factors of public sector bank which provide predominate role to influence people in low income or middle income group to leaver towards financial inclusion, the components were divided in to three major category, government active participation on which Pradhan Mantri Jan DhanYojana has been most favored factor of $74.7 \%$ followed by Self- help groups has more grip in rural as well as some part of urban sectors and some customer avail for schemes provided by the government. The second category was Financial assistance where availability of features like gold loan $72.8 \%$, low interest loan, easy monthly installment benefits along which personal loan also plays major role, that low income or middle income group volunteer themselves in for case of future reliance avail Employee provident fund $80 \%$ inducement in participating themselves in financial inclusion following along with savings considered as next active reason. The empirical correlation study has been founded that there is a noted relationship between the academic qualification and the awareness of the other services offered by the bank towards customers of middle income and low income group such as loans/internet mobile banking/credit card debit card /insurance services and other financial services such as demat, mutual funds and other government and private bonds. That the services provided by public sector bank was utilized efficiently with the literacy level, that is the educational qualification have medieval impact on analyses and utilization of various schemes and services offered by the public sector bank which help in effective improvement on financial inclusion under low or middle income group customers.

\section{CONCLUSION}

The study has been factorized the various measures taken by the public sector bank towards low income and middle income group to take part in financial inclusion ideology, the behavioral pattern has been factorized and features have been prioritized, like various yojnas of government influencing the public in mass factors like Pradhan Mantri Jan DhanYojana, the knowledge of factor availability through public sector bank over financial assistance on crisis, lead this particular income to opt for organized financial banking sector instead of unorganized sectors, public sector bank also provide the scope to the group over reliance components. The qualification and educational intelligences provide moderate motivations on identification of services and application on the same with the guidance of public sector banks. Public sector bank playing leading responsibility over financial inclusion over India and massive pillar of government measures and implementing the same among general public throughout the rural and urban stakes of the country.

\section{SCOPE OF FUTURE STUDY}

The subject is limited to only public sector bank which can be carried out for various other institutions working for the welfare of economy. The comparative study can be made with public and private sector bank for their active participation on financial inclusion to the economy. The study can be made for role of government in other beneficial scheme which inclusive the economic growth.

\section{REFERENCES}

1. D.B.Bharathiinternational journal of basic and applied economics 1(2), 39-44, 2016.

2. M.P.Desai(2016)-Scenario of Financial Inclusion- paripex - indian journal of research ISSN - 2250-1991 ;IF: 5.215 ;IC Value: 77.65

3. Ramesh Iyer Vice Chairman and Managing Director, Mahindra Finance, 14 Jan, 2019 "financial inclusion in India is soaring: Here's what must happen next on e-journal of world economic forum" https://www.weforum.org/agenda/2019/01/financial-inclusion-in-india-issoaring-heres-what-must-happen-next/.

4. SethySusanta Kumar (2016), "Developing a financial inclusion index and inclusive growth in India Theoretical and Applied Economics" 23(2), 187-206. 
5. Singh, Charan and Naik, Gopal, Financial Inclusion in India: A Case Study of Gubbi (May 25, 2017). IIM Bangalore Research Paper No: 549. Available at SSRN: https://ssrn.com/abstract $=2973741$ or http://dx.doi.org/10.2139/ssrn.2973741.

\section{AUTHORS PROFILE}

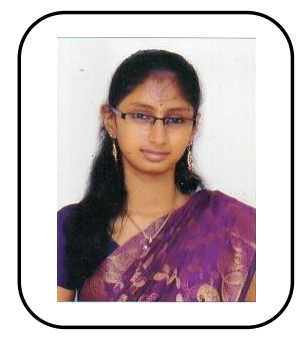

Ms. Keerthika. R has completed her Master of philosophy in commerce and has worked in Prince Venkateshwara Arts and Science college for one year as Assistant Professor. She has presented research papers in international conferences published in UGC care journals.

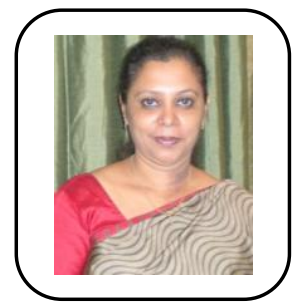

Dr. Anli Suresh joined the department as a faculty in the year 2004. Her area of specialization is Finance. Her doctoral research was on "A STUDY ON PARADIGM SHIFT IN FINANCIAL INNOVATION AND CAPITAL FORMATION IN INDIAN FINANCIAL SYSTEM WITH REFERENCE TO POST LIBERALIZATION ERA". She has also cleared NET, the National Eligibility Test for lectureship conducted by University Grants Commission, India. She has presented many research papers in national and international conferences organized by various universities across the county and her papers awarded as best paper in many conferences. Her research and teaching interests include Financial Management, Quantitative Techniques with SPSS, Brand Management, Income Tax, Banking, Organizational Behavior, Strategic Marketing, Training and Development, Services Marketing, Accounting for Decision Making. She has published more than 100 of her research papers in various reputed referred national, international journals and books and organized many international conferences. She is also in the editorial board of international journals to her credit. In the year 2010-2011, Ms. Anli was chosen as the distinguished fellow of Global Strategic Management Inc, Michigan, USA. 